\title{
THE POLITICAL PUBLIC SPHERE AS THE MAINTENANCE OF ORDER: CONVERGENCE IN HANNAH ARENDT AND JURGEN HABERMAS
}

\author{
FAHRIYE ÜSTÜNER* \\ Middle East Technical University
}

\begin{abstract}
H. Arendt's and J. Habermas' conceptions of public sphere often have been studied independently in the literature. This article brings and analyzes them together on the common basis of the model of "political public sphere." For both thinkers, the public sphere is a site of free and equal deliberation based on regulative principles; and it serves the creation of a collective will around matters of common concern. The article argues that this model reduces the scope and meaning of politics for the sake of developing an "ideal" and "true" politics or a "legitimate and democratic" politics, also referring to the distinction between "politics" and "police" made by J. Rancierè.
\end{abstract}

Key words: Arendt, Habermas, political public sphere, politics, democracy, exclusion.

\section{DÜZENIN DEVAMI OLARAK SIYYASAL KAMUSAL ALAN: HANNAH ARENDT ILE JURGEN HABERMAS'IN YAKINLASBMASI}

\author{
$\ddot{O Z E T}$
}

Bu çalışmada, H. Arendt'in ve J. Habermas'ın literatürde çoğu zaman birbirinden ayrı ele alınan kamusal alan kavramlaştırmaları, her ikisinin de ortak çerçevesini oluşturan 'siyasal kamusal alan' modeli ekseninde incelenmiştir. Her iki düşünür de kamusal alanı öznelerarası iletişim alanı olarak ele alır ve genele ait meselelerin katılımcllarca eşit ve özgür olarak, birtakım düzenleyici ilkelere göre tartışılmasını ve sonuçta bir anlaşmaya varılmasını amaçlarlar. Makalede, bu modelin "ideal" ve "doğru" siyaset (Arendt) ya da toplumsalın bütünleşmesini sağlayacak "meşru ve demokratik siyaset” geliştirme uğruna (Habermas) siyasetin alanını ve anlamını daralttığı savunulmuş ve bu fikir J. Rancierè'in "siyaset" ve "police" ayrımıyla desteklenmiştir.

Anahtar kelimeler: Arendt, Habermas, siyasal kamusal alan, siyaset, demokrasi, dışlama.

The concept of public sphere and especially the distinction between the public and the private spheres has always occupied an important place in western political thought. Further, the concept has been utilized widely as part of efforts to develop democratic politics in recent years albeit different meanings have been attached to it by different thinkers.

* Fahriye Üstüner is an Assistant Professor in the Department of Political Science and Public Administration at Middle East Technical University, 06531, Ankara, Turkey. E-mail: ozcoban@metu.edu.tr 
In the literature, it seems possible to find various attempts to classify different approaches to the concept of public sphere and the distinction between public and private. For example, Benhabib (1992: 89) mentions four public sphere models: the liberal model, the civic virtue or the republican model, the discursive model of public space and the feminist model that is critical to the distinction. Weintraub (1997: 7) follows a similar pathway when he cites different approaches to public sphere such as the liberal model, the republican virtue model (classical model), the public life as sociability model and the critical feminist perspective.

This article focuses on Hannah Arendt and Jurgen Habermas' conceptions of the public sphere as the basis of politics, political community and active citizenship/participation that is supposed to enable the "true politics" (Arendt) and/or democratic-legitimate politics (Habermas). Despite the fact that they stand at different philosophical positions in general, they converge on their analysis of the public sphere. This makes their comparison possible. Both thinkers conceive the public sphere on the basis of intersubjective communication that is expected to create a collective will in society. Benhabib states that Habermas' "theory of communicative action" was much influenced by Arendt's "linguistic structure of human action." She also writes that, "Arendt's concept of public space is the second and equally important conceptual legacy that she imparted to Habermas" (2000: 199). ${ }^{(1)}$ In this context, when their conceptions of the public sphere are analyzed on the basis of their common concern that aims to generate the principles of "true politics" or "legitimate and democratic politics" through the public sphere, then Republican Arendt and non-Republican Habermas may be situated under a single model that I prefer to call "the political public sphere" model.

To give a comprehensive overview of the political/social theories of Habermas and Arendt and to compare and contrast their approaches remains outside the scope of this paper. Rather, this study attempts to show how both thinkers, through their own conceptualizations of public sphere, conceive politics, and advocate a certain and limited understanding of social/political relations. This argument will be elaborated with reference to an alternative position, the one provided by Jacques Rancierè, who sees politics as a moment of challenging the existing order by the excluded voices.

\section{FROM THE PUBLIC SPHERE AS A SPHERE OF ACTION TO THE PUBLIC SPHERE AS A SPHERE OF JUDGMENT: THE POLITICAL PUBLIC SPHERE IN ARENDT'S THOUGHT}

In Hannah Arendt's thought, the importance of politics and its main ground for action, the public sphere, is best conceived by her "vita activa" concept:

With the term vita activa, I propose to designate three fundamental human activities: labor, work, and action...Labor is the activity which corresponds to the biological process of the human body... Work is the activity which corresponds to the unnaturalness of human existence, which is not embedded in, and whose mortality is not compensated by, the species' ever-recurring life cycle...Action, the only activity that goes on directly between men without the intermediary of things or matter, corresponds to the human condition of plurality, to the fact that men, not Man, live on the earth and inhabit the world. While all aspects of the human condition are 
somehow related to politics, this plurality is specifically the condition -not only the condito sine qua non, but the condito per quam - of all political life (Arendt, 1958: 7).

Among these three human activities, action is the most political one. This is mainly because of the fact that whereas labor and work can be realized in the absence of others, action necessitates the presence of other people as it "can not even be imagined outside the society of men" (Arendt, 1958: 22). In this context, action constitutes the human interaction that shapes public life through the intimate relationship. As such, it is only viable through human plurality. Arendt emphasizes the importance of equality and distinction being two main features of human plurality. For her:

If men were not equal, they could neither understand each other and those who came before them nor plan for the future and foresee the needs of those who will come after them. If men were not distinct, each human being distinguished from any other who is, was, or will ever be, they would need neither speech nor action to make themselves understood (Arendt, 1958:175-6).

Distinct and equal individuals, as they come into interaction through speech and action, constitute the public sphere as the political space.

Arendt's identification of action and speech with politics gets its roots from Ancient Greek thought and practice where politics was defined and exercised as a process of persuasion through speech, ruling out force and violence in a polis (Arendt, 1958: 26). The emergence of the city-state resulted in the formation of two distinct spheres: the private and the public. The private sphere represented the space of the useful and necessities and was essential for the survival of human beings. The public sphere represented interaction through speech (lexis) and action (praxis) and was the space of freedom. Citizens expressed their being through speech and action in the public sphere whereby the useful and necessities of the private sphere were excluded:

The term "public" signifies two closely interrelated but not altogether identical phenomena: It means, first, that everything that appears in public can be seen and heard by everybody and has the widest possible publicity... Second the term "public" signifies the world itself, in so far as it is common to all of us and distinguished from our privately owned place in it (Arendt, 1958: 50-2).

Arendt's dual definition of the word "public" is related directly to her twofold usage of action and the public sphere. While Maurizio D'Entrèves underlines two different meanings of action in Arendt's thought, Seyla Benhabib does the same for her understanding of public space.

D’Entrèves (1994: 10, 84) states that Arendt defines action in the public sphere as a human activity in which "individuals are able to disclose their identity, their distinctive "who" as against their shared "what." D'Entrèves, elaborating Arendt's position, calls this sort of mode of action "expressive action." The second meaning of action is based on reciprocal relations and togetherness aiming at solidarity through persuasion. D’Entrèves, following Habermas (1977), calls this type "communicative action." This communicative action, for Arendt, is the basis of a political realm that is constituted by the "sharing of words and deeds" (Arendt, 1958: 198). 
Benhabib (1992) differentiates Arendt's views on the public sphere as "agonistic" and "associational." The agonistic public sphere is about the uniqueness of human beings and it "...represents that space of appearance in which moral and political greatness, heroism and preeminence are revealed, displayed, shared with others" (1992: 93). In the associational type of public sphere, human beings interact through a concerted action, thus maintaining collectivity.

It is possible to establish a link between D'Entrèves and Benhabib's classifications. The space in which "expressive action" is displayed corresponds to the "agonistic public sphere." Similarly, "communicative action" takes place in the "associational public sphere."(2) When taken together with Arendt's conceptualization of plurality, the agonistic public sphere becomes important for humans to reveal their distinction through expressive action and in the associational public sphere, equality through communicative action becomes prominent.

According to Arendt, since power is generated out of people coming together and getting involved in collective action (1958: 244), and since this takes place among equal fellows, power is a property of the public sphere and equality. This rather unusual understanding of power assumes an equal relationship in which subordination is not the primary characteristic. Subordination, in this context, is the property of the private sphere and is kept away from the public sphere. This results in a specific understanding and practice of politics that does not comprise any sort of inequality or unequal relations and thus rejects conflict out of these. Politics, seen in this way, also excludes any potential struggle to be undertaken against inequality. As is argued by Craig Calhoun, for Arendt (Calhoun, 1997: 9),

...politics, in such a conception, cannot be merely a matter of power, of division between ruler and ruled, or of distribution of economic goods. Politics has to be, among other things, a realm of self-creation through free, voluntary action undertaken in consort with and in relation to other people. The public realm in which politics takes place is above all else a space between people, created by their discourse and mutual recognition.

Arendt, in her later works, added Kant's concept of "faculty of judgment" to her view of associational public sphere and communicative action to elaborate a "true" politics for modern times in which, the "ideal" public sphere has disappeared. Before the analysis of the situation of true politics, it is more convenient to discuss the disappearance of public space which was experienced in ancient Greece typically, as Arendt assumes.

\section{THE RISE OF THE SOCIAL, THE DISAPPEARANCE OF THE PUBLIC SPHERE}

According to Arendt, the division between the public and private spheres vanished with the appearance of society in modern times, especially with the emergence of the nation state. She likens national economies to "collective housekeeping" consisting of individual families, the totality of which is called "society." What is called nation, she argues, is the political form of society, or the "super-human family" (Arendt, 1958: 28-9). 
In this context, for her, "true" politics necessitates a clear-cut separation of private and public spheres; issues pertaining to the private should remain there. According to her, the Ancient Greek model and the "polis" were good and idealized examples of such a setting. This view has generated some criticisms of her approach. The main reason for this is the fact that the polis model excluded certain human beings from the political sphere. ${ }^{(3)}$ For Arendt, this is not a major problem. Further, this is a kind of "safeguard" for the proper functioning of the public sphere. The excluded, with all their inequalities, are kept in the private sphere and since the spheres are distinct, these are not allowed to interfere there. Put in other words, "...the mastering of the necessities of life in the household was the condition for freedom of the polis" (Arendt, 1958: 29). Despite the evidence that she was aware of the possibility that the number of the excluded people overwhelmed the number of citizens, ${ }^{(4)}$ Arendt did not directly address or was not concerned with this issue in her work. In fact, the possibility and legitimacy of exclusion of the masses from the arena of politics for the sake of maintaining the idealized public sphere conditions is characteristic of her thought and will be treated further in this study.

Another consequence of the rise of society is the "equality" problem. According to Arendt, in Ancient Greece, this was a matter of equality among equals. However, with the rise of society, the equality understanding that had previously been relevant to the private sphere was transformed to the public sphere. The despotic relationship between the "householders" and the "household head" became the rule of society in general, "... except that in society, where the natural strength of one common interest and one unanimous opinion is tremendously enforced by sheer number, actual rule exerted by one man, representing the common interest and the right opinion, could eventually be dispensed with" (Arendt, 1958: 40). The type of equality in modern times which brings "equality to the unequal" basically through the system of law of the nation (as opposed to the "equality of the equals"), may cause the true and ideal politics to fade away.

In a similar fashion, the plurality that emerged with society in modern times is not proper. This is because of the fact that people who resemble one another and are alike in many respects not only cannot constitute the plurality, but may even suppress it. According to Arendt, since uniqueness is repressed, plurality among people is ruled out and uniformity and sameness have become widespread in modern times. She states that "the end of the common world has come when it is seen only under one aspect and is permitted to present itself in only one perspective" (1958: 58).

Naturally, with the end of uniqueness and thus plurality, being the ground of proper politics, the public sphere has disappeared. Here, before anything else, Arendt's conception of plurality based on uniqueness and equality should be questioned. The overwhelming number and diversity of the excluded, as already mentioned, directly limits the variety of the unique traits to be present in the form of plurality in the public sphere. Added to this is the problem of considering uniqueness as something derived from the individuating of difference. Thus, equality becomes a "generic equality" (Benhabib, 1992: 126) possessed only by being a human, rather than a political equality and difference. To define politics within the context of this limited understanding of equality, difference and plurality restrains it and seriously limits the boundaries and the meaning of the public sphere.

The disappearance of the public sphere with the emergence of the social seems to force Arendt to seek and set down certain principles of true politics in modern times. For that purpose, Arendt refers to Kant's conception of the "faculty of judgment" and tries to derive the principles by attributing a political meaning to it. ${ }^{(5)}$ 


\section{POLITICS AS A FACULTY OF THE JUDGMENT OF ACTORS}

Arendt seems to revive the ideal public sphere understanding as assumed to have existed in Ancient Greece based on Kant's theory of faculty of judgment in modern times. This brings forth intersubjective communication within the public sphere. According to Arendt (1982: 4), judgment is "the most political of man's mental abilities" and it is "the political faculty par excellence." Arendt focuses on Kant's political philosophy and especially his Critique of Practical Reason in order to grasp the faculty of judgment "in its proper perspective" and its political implications. For Arendt, Kant's perspective in his Critique of Practical Reason is not sufficient to politicize the judgment. Kant's way of thinking in his Critique of Judgement is more helpful for this purpose. According to Arendt, among the three faculties of human beings (willing, thinking and judging), only the last one is political since it is the only one that necessitates the presence of others. In this context, faculty of judgment becomes essential for politics and the public sphere. In her studies, however, two different versions of relating this concept to politics can be tracked. The first version, as is evident in her early studies, is related to the faculty of actors whereas the second one adds the judgment of spectators who remained outside of the action. The faculty of judgment as related to the actors is relevant to the "associational" model of public sphere and the appropriate action for this is the "communicative action.”

She states that:
the power of judgement rests on a potential agreement with others, and the thinking process which is active in judging something is not, like the thought process of pure reasoning, a dialogue between me and myself, but finds itself always and primarily, even if I am quite alone in making up my mind, in an anticipated communication with others with whom I know I must finally come to some agreement. From this potential agreement, judgement derives its specific validity. This means, on the one hand, that such judgement must liberate itself from the "subjective private conditions", that is, from the idiosyncrasies which naturally determine the outlook of each individual in his privacy and are legitimate as long as they are only privately held opinions, but which are not fit to enter the market place, and lack all validity in the public realm. This enlarged way of thinking, which as judgement knows how to transcend its individual limitations, cannot function in strict isolation or solitude; it needs the presence of others "in whose place" it must think, whose perspective it must take into consideration, and without them it never has the opportunity to operate at all (Arendt, 1968: 220-1).

In this "enlarged way of thinking," or as Kant calls it, "enlarged mentality," actors should not only agree with their own self, but they also should put themselves in the place of other people and try to see the world from their perspective. According to Arendt this is what politics and political thinking is all about; “...taking other people's opinions into account is the hallmark of all strictly political thinking" (Arendt, 1968: 241). This "representative way of thinking" is important and maintains a "collective" thinking and action against individualism of the self and her/his private interests (or, as Arendt calls it, "the liberation from one's own interests" [1968: 241-42] ). Arendt states that as more 
people think in the representative way, judgment from the vantage point of the others, the conclusions and final decisions will be more valid and acceptable by all. This also allows a situation in which many voices are expressed as one and which may be called an unidentified view that is both one of everybody and one of nobody at the same time. This is, for her, politics par excellence. Therefore, when every participant is able to use her/his faculty of judgment, agreement is easily reached, but the borders and meaning of politics is restricted, “...the concern of politics is to arrive at general, impartial, 'enlarged' public opinion through 'persuasion' and 'discussion'...” (Riley, 1992: 318).

\section{POLITICS AS A FACULTY OF THE JUDGMENT OF SPECTATORS}

The second meaning attributed to the faculty of judgment by Arendt may be found in her unfinished work, The Life of the Mind (1978) ${ }^{(6)}$ In that study, the space of politics is further limited. ${ }^{(7)}$ Here, the focus is shifted to the spectators of the political action. Put in other words, an action performed by the actor by using her faculty of judgment is assessed by the spectators in terms of its being right or not and being political or not. This assessment, in fact, is based upon Kant's "reflective judgment" understanding. This is necessary especially when the spectator has no universal criteria from prior experience to use for making that assessment. Being critical is the condition of "reflective judgment." This is because the critical thinking "...exposes itself to 'the test of free and open examination' and this means that 'the more people participate in it, the better"' (Arendt, 1982: 38).

Critical thinking, in return, necessitates "publicness" since it is impossible to be critical in the absence of contact with others, their thinking and inspection. Publicness means here the "enlargement of mind" by being both critical of and caring for others' thoughts. Adopting Kant's moral philosophy, Arendt states that if an action is done or evaluated with a maxim that does not take others' thinking into consideration (publicness) it will not be a "right" action. The opposite would mean to insist "to be evil," to withdraw from the public realm (1982: 49). In this context, the necessary maxim that enables the publicness of the private or the particular is the "communicability" principle. The communicability principle is needed to transform the interest/idea of the particular into the interest/idea of the general, to turn the private problem into a problem of the public. The communicability principle also makes the actions moral and this is essential for true politics. However, it should be remembered that it is still the spectator, not the actor, who may evaluate the morality of the action. The spectator, to be able to make this evaluation, must be disinterested, not participating in, and noninvolved with that event (issue). This being the case, many situations that do not comply with the maxim (communicability) in the eye of the spectators are likely to be excluded from the subject and the agenda of politics such as politics of identity, covert political actions and the like. Beiner emphasizes this shift in Arendt's definition of politics as follows:

In the earlier formulations we find discussions of the relation of judgement to "representative thinking" and opinion, leading one to suppose that judgement is a faculty exercised by actors in political deliberation and action...But this approach is implicitly denied in her later account (Beiner, 1982:138-39).

In this sense, the meaning of politics for Arendt shifts from the free deliberation of ideas, the exchange of opinions and the generation of judgment of equal participants in the public sphere to the judgment of the spectator. 
Arendt's views seem to be an attempt to regulate (if not control) the public sphere so as to make it the ground for true and moral politics as against the self-interested, individualized and immoral politics of the modern times. The way of such regulation for her is restricting the space of politics, if not totally rejecting it, since the process of giving a meaning to politics is left to the process of judgment of people who are not necessarily interested parties. ${ }^{(8)}$

Despite Arendt's dual conceptualizations and unclear argumentations, her concern for collective action, the priority of the publicness over the private and seeing politics as an ontological property of humanity within her own context allow us to consider her approach as part of a democracy understanding shaped by the communicative action. However, this is a limited democracy understanding since especially differences and identity politics are excluded if not eroded by being publicized. ${ }^{(9)}$ The excluded, in this context, may only express themselves if they are successful enough to convert the particular into the universal, otherwise there will be no room for their survival and participation. Such a conversion would mean the self-destruction of their own particularity and difference.

On the other hand, Habermas (1977) considers Arendt's approach to the public sphere especially within the context of the "ethics of communication." Yet, he emphasizes the need for a "procedural" regulation of the communicative action. This seems to be a major motivation behind his formulation and elaboration of "theory of communicative action" and "discourse ethics."

\section{THE TRANSFORMATION OF THE PUBLIC SPHERE IN HABERMAS' THOUGHT}

Arendt centers her ideal model of the public sphere and politics in the Ancient Greek experience and accepts its decline with the rise of society or the modern world. On the contrary, Habermas' ideal form of the public sphere belongs to modern times, and its decline is also peculiar to the modern era. In his thought, the public sphere remains outside of the state but still is related to it. It stands inbetween civil society and the state. Therefore, the emergence of the public sphere is dependent on the rise of modern society and the state. ${ }^{(10)}$ Habermas explains the nature of the public sphere by analyzing historical developments and focuses on grasping the modern public sphere in relation to the state, family and the features of civil society. In this sense, the public sphere stands separated from and against the state, distinct from family and the economy/market. Its members have a critical and argumentative relation towards it from the outside. They can influence the outcomes of the state and try to control it, but they themselves do not posses its power. Family is a part of the private sphere, as in the Ancient Greek practice and in Arendt's thought, but unlike these - and similar to the liberal understanding - freedom exists there. Furthermore, the formation of the identity of individuals as private persons is constituted within the family so that they can enter into the political public sphere. ${ }^{(11)}$ Similarly, the economy takes place in civil society and it is outside of both the family and the state. In this sense, Habermas' conception of the public sphere is a combination of liberal and republican themes yet is different and distinct from them. This position is still visible in his recent studies.

In Habermas' original theory, the bourgeois generates the public sphere. This is because: 
In its clash with the arcane and bureaucratic practices of the absolutist state, the emergent bourgeoisie gradually replaced a public sphere in which the ruler's power was merely represented before the people with a sphere in which state authority was publicly monitored through informed and critical discourse by the people (McCarthy, 1989: xi).

According to Habermas, the main instrument that enables the rational-critical reasoning is the press. By the early eighteenth century, the press began to fulfill the function of rational-critical reasoning, and by the second half of the eighteenth century, the term public opinion arose. Consequently, "the critical process that private people engaged in rational-critical public debate brought to bear on absolutist rule" (Habermas, 1989: 102). The public sphere which emerged by that process was privatized, against the public authorities, and as Calhoun (1992: 9) mentions, was a public "practice of rational-critical discourse on political matters." That critical function initiated by the press continued later in the "literary public sphere" and "coffee houses" (in England), salons (in France) and "table societies" (in Germany)." The main features of the public sphere were accessible to all, initiated equality by eliminating privileges, and provided a medium for discussions on topics hitherto inaccessible and unknown.

Later, the literary public sphere was transformed into the political public sphere. Habermas explains this transition as follows:

As soon as privatized individuals in their capacity as human beings ceased to communicate merely about their subjectivity but rather in their capacity as property-owners desired to influence public power in their common interest, the humanity of the literary public sphere served to increase the effectiveness of the public sphere in the political realm (1989: 56).

Therefore, the literary bourgeois public sphere began to play a political role when it engaged in the discussion of common affairs and especially state policies. In such a public sphere, for Habermas, there is no place for particular interests. Similar to Arendt's arguments, Habermas also sees the public sphere as the medium through which private and particular issues are eliminated.

However, in the mid-nineteenth century, with the rise of mass-culture and mass society, the distinction between the public sphere and the private sphere was blurred and the bourgeois public sphere went into a disintegration process, and the result was the "refeudalization of society." Mass culture dominated the public sphere through all its commodified relations, advertisements and propaganda, thereby making it unpolitical and "pseudo-privatized." "The infusion of private interests made the separation of public and private and thus the functioning of the public sphere inapplicable" (Habermas, 1989: 176). This meant a shift in the meaning of publicity, changing from publicness with critical-rational debates on common affairs to an arena of interest-based politics and actions mainly initiated by journalism, advertising and propaganda.

In his later works, as will be discussed in the next part of this study, Habermas tries to revive the attributes of the bourgeois public sphere of the eighteenth century in late capitalist society through 
his communicative action theory and its combination with morality, that is, discourse ethics. He sees communicative rationality and discourse ethics as capable of enabling democracy and legitimate politics in advanced capitalist society.

\section{COMMUNICATIVE ACTION AND DISCOURSE ETHICS AS THE REGULATIVE PRINCIPLES OF THE PUBLIC SPHERE}

In The Theory of Communicative Action $(1984,1987)$, Habermas mentions two types of actions based on different rationalities and defines the appropriate levels of society for their operation. ${ }^{(12)} \mathrm{He}$ calls these purposive-strategic action and communicative action. Purposive-strategic action aims to influence the decisions of other actors to realize their own goals. Communicative action refers to the distinctive type of human interaction revealed in intersubjective communication and communicative rationality. Its aim is to arrive at mutual understanding and it is a process of reaching agreement between speaking subjects (Habermas, 1984: 285-86). Two different levels of society appropriate for these two types of rationality and action are "lifeworld" and "system." The lifeworld is a "necessary complement to the concept of communicative action" and it is related to the "context-forming horizon of social action" (Habermas, 1984: xxiii). It consists of certain assumptions, cultural norms, expectations, and meanings utilized by human beings to interpret their own life experiences and guide them in their relations with others (McAfee, 2000: 85). The other level of society is the system which consists of the division of labor and functions organized into distinct spheres of actions and goals (McAfee, 2000:85). Habermas names money and power as part of this level, in fact, these represent economy and "administration" in a society (Habermas, 1987: 262-63). According to Lenoble, these two "functions" are separated autonomously and governed by specific codes of money in the economy and power in administration (Lenoble, 1998: 41-2). Habermas states that if the system begins to shape and determine the lifeworld, the result will be a "colonization" of it and this situation will pose an obstacle to social interaction and democratic politics.

Habermas aims to prevent this undesired situation of the colonization of the lifeworld. For this purpose, he tries to revitalize the separation of the private sphere from the public sphere, as was the case in the eighteenth century. Situating the economy and administration (money and power) within the system that operates according to purposive-strategic rationality and action, he seeks to mitigate their negative intervention into the lifeworld (and the public sphere) which, as already mentioned, is the main reason for the "refeudalization" of society. ${ }^{(13)}$

Habermas" "discourse ethics," which is based on moral theory, seems to be the safeguard against the "colonization of the lifeworld." This is because his discourse theory gives us the procedure of deliberation among the contentious values and ways of life, especially for societies with plural life styles and values. The procedure of deliberation is essentially an ideal form of communication between controversial ideas and values made through linguistic processes. The norms to be used during that process also are bounded by this acceptance that "whether a norm is justifiable cannot be determined monologically, but only through discursively testing its claim to fairness" (McCarthy, 1991: viii). This procedure is centered on the "intersubjective recognition of (the) validity claims" of the deliberating participants to reach an agreement. 
In cases where agreement is reached through explicit linguistic processes, the actors make three different claims to validity in their speech acts as they come to an agreement with one another about something. Those claims are claims to truth, claims to rightness, and claims to truthfulness, depending on whether the speaker refers to something in the objective world (as the totality of existing states of affairs), to something in the shared social world (as the totality of the legitimately regulated interpersonal relationships of a social group), or to something in his own subjective world (as the totality of experiences to which one has privileged access (Habermas, 1991: 63).

The "intersubjective recognition" of others' claims, before all, is based on a mutual acceptance of satisfying the interests of all participants. This is related to the "principle of universal" that is needed to convert argumentation into a "moral argumentation" and comes to mean that "all affected can accept the consequences and the side effects its general observance can be anticipated to have for the satisfaction of everyone's interests"(1991: 65) .

The participants of the argumentation should leave their own particularities (which should be kept at the level of system) aside when they enter into the deliberation of common issues. This is possible when the participants adhere to a moral procedure and accept the validity of certain assumptions. ${ }^{(14)}$

It seems that Habermas aims to draw the lines for a morality of procedures (rather than morality of individuals) of collective action in the form of deliberation on controversial issues. He finds this necessary to maintain social integration and legitimate/democratic politics in late capitalist society which consists of self-interested individuals. In this context, these individuals are allowed to pursue their own personal interests outside the "public sphere" where the deliberation on common matters takes place. During the deliberation process, contesting arguments are expected to be expressed freely; however, as this process itself is subject to predefined procedures (discourse ethics) to make agreement and collectivity possible, their particularities become evanescent. As McCarthy notes (1991: ix),

Habermas' discourse model, by requiring that perspective-taking be general and reciprocal, builds the moment of empathy into the procedure of coming to a reasoned agreement: each must put himself or herself into the place of everyone else in discussing whether a proposed norm is fair to all. And this must be done publicly... ${ }^{(15)}$

Thus, particularities should be converted to expressions that may be accepted by all. Otherwise, deliberation ceases to exist, or those who do not obey the procedures are excluded from the process. This results in the important problem of "exclusion." As already noted, this problem also is relevant to Arendt's approach as well.

\section{THE PROCEDURALIST UNDERSTANDING OF DEMOCRACY AND POLITICS}

In his book Between Facts and Norms: Contribution to a Discourse Theory of Law and Democracy (1996), Habermas mentions the notion of the "proceduralist understanding of law." In general, he tries 
to establish a link between "system" and "lifeworld" through the political public sphere where "opinion-and will-formation" is generated. For him, this is necessary for a democratic and legitimate politics. "Opinion-and will-formation" in the political public sphere is in fact, the deliberation made according to discourse ethics' rules and the resultant collective will is turned into laws by the parliament. This means the conversion of collective will into the language of the "system": "law is the sole medium through which the communicative power of citizens can be transformed into administrative power" (Baynes, 1995: 213). By this understanding, Habermas indicates that the source of legitimate laws in a society is civil society, the public sphere, and the communicative power that is generated from their interactions. He underlines two important components of this process as the inclusion of private “... actors' qualities, competences, and opportunities" (1998: 18) and the conversion of these into the public sphere by various "forms of communication., ${ }^{,(16)}$ Discourse ethics being one of these forms of communication is important since it is the means by which to translate "informal and noninstitutionalized opinion and will formation" into a political order of "institutionalized deliberation." Based on this process, the transformation of the collective will into general laws constitutes the basis of legitimacy of politics and democracy:

a legal order is legitimate to the extent that it equally secures the cooriginal private and political autonomy of its citizens; at the same time, however, it owes its legitimacy to the forms of communication in which civic autonomy alone can express and prove itself. This is the key to a proceduralist understanding of law (Habermas, 1998: 19).

The proceduralist understanding of law makes politics open and sensitive to voices from the lifeworld thus eliminating its self-referentiality. At this point, the question of which "voices" and through which mechanisms this inclusion process will be realized becomes important. The answer to this question is in Habermas' distinction of the public sphere(s) and the political public sphere. The public sphere is " .... communication structure rooted in the lifeworld through the associational network of civil society” (1996: 359). Through various forms of communication as well as bargaining and negotiation, disputes and particular demands are discussed. Once these particularities are converted into common matters and issues of general interest, they become the subject of the "political public sphere" where they are deliberated, expected to be resolved and turned into public will. This will is passed to the parliaments, considered as "strong publics" (Baynes, 1995: 217) or "more formal deliberative bodies" (McAfee, 2000: 91), where they are turned into laws. In this context, the public sphere “...should be seen as a double one, distinguishing not only organizationally but in terms of their very structure between civil publics and the publics of formal political institutions: parliaments and courts" (Arato, 1998: 33).

Under such a system, through these levels of sub-networks and their filtering, private interests and demands are translated into common matters and to the concern of the public network. This filtering includes both the elimination of the particular and the resolution of disputed issues. Done in this fashion, politics and legislation become legitimate and put under the control of procedures that govern all stages of this process. This helps the reproduction of the social by ruling out conflicts that bear the potential to give harm to the integration of society.

In this context, procedures that govern the deliberation process on the basis of discourse ethics become important constituents of Habermas' democratic politics understanding. Discourse ethics 
play a vital role in both the formation of the public opinion/collective will on societal matters and the law-making process itself:

...the only regulations and ways of acting that claim legitimacy are those to which all who are possibly affected could assent as participants in rational discourses. In the light of this "discourse principle," citizens test which rights they should mutually accord one another. As legal subjects, they must anchor this practice of self-legislation in the medium of law itself; they must legally institutionalize those communicative presuppositions and procedures of a political opinion- and will-formation in which the discourse principle is applied...discourse principle acquires the legal shape of a democratic principle (Habermas, 1996: 458).

The political public sphere can be created when the participants apply the discourse principle to the communication that enables "the political opinion- and will-formation." Thus, the shift in his conception of public sphere is also observed by Hirschkop (2004: 51):

The public sphere in Habermas' initial formulation was the compact historical achievement of a particular class. As time went by, however, the concept of the public sphere was 'linguistified', made fluid and mobile to the point where it was not a space in which a certain kind of communication could take place, but a space generated by a certain kind of communication.

Habermas emphasizes that his proceduralist discourse theory of democracy ("deliberative model of democracy") is different from both liberal and the republican views:

Discourse theory invests the democratic process with normative connotations stronger than those found in the liberal model but weaker than those found in the republican model...it takes elements from both sides and puts them together in a new way. In agreement with republicanism, it gives center stage to the process of political opinion-and will-formation, but without understanding the constitution as something secondary;...Like the liberal model, discourse theory respects the boundaries between "state" and "society," but it distinguishes civil society, as the social basis of autonomous public spheres, from both the economic system and public administration (Habermas, 1996: 298-99).

The proceduralist understanding of law ties "political opinion-and will-formation" and political system to the networks of public spheres in civil society. Thus, on the one hand, opinion and will formation are proceduralized and institutionalized, while on the other hand, political/administrative system is conceived in relation to civil society through his proceduralist understanding of law. Habermas is in parallel with the republican view when he mentions public opinion and will formation, but leaves that view when he attempts to procedurialize and institutionalize it. Similar to liberals, Habermas conceives state and civil society as distinct spheres, but unlike them, he separates economy from civil society. Furthermore, the subjects of this process are different from both the 
liberal and republican views; they are neither self-interested nor "ethically overburdened," but are bounded and committed to the rules of the procedure only in the communication. Individuals do not have substantial norms and values predetermined by a society, but they should be competent to decide on the appropriate form of communication and use it in the deliberation process. This means that "they implicitly take on the burden of redeeming claims they raise to others regarding the truth of what they say, its normative rightness, and its sincerity" (White, 1995: 7).

Thus, Habermas tries to elaborate on the alternative radical democracy understanding that is linked to liberal and republican views, but is still distinct from them. It seems that his main concern and objective are to tempt the liberal-self interested individual to get involved in the collective action. Put in other words, he tries to convert the self-interested individual into a self-governing citizen as in the republican view, but unlike that, he assumes this is possible without necessarily sharing substantial values, but through communication and deliberation in the political public sphere. Such a process necessitates the conversion of individual interests and values into a new ground of politics that is shaped by a moral-proceduralist framework. Each participant in that process, even those without moral foundations, must be mature and intellectually capable of understanding other people (Warren, 1995). Therefore, according to Habermas' view, politics directly depends on interaction and mutual understanding between individuals who have "...ideology-free dialogue oriented towards genuine consensus with respect to issues of public concern” (Gardiner, 2004: 30).

Habermas naturally is concerned with the possibility of disagreement in that communication process: "Also communicative actor's orientation to agreement does not exclude the possibility of dissent as the result of distorted or unresolved communication" (Deflem, 1996: 3). In that case, however, there is no possibility of the continuation of deliberation, so the political process ends. This results in the reproduction of the existing situation without any change. This argument further confirms that in Habermas' understanding of politics, there is almost no room for systemic dissensus or disagreement. When this is the case, the participants of the political public sphere always have to seek "...the one right answer to a practical-political question" (McCharthy, 1998: 137). Differences, in Habermas' view, reside in the existence of different public spheres and should be kept there. These should never be allowed to be brought into the political public sphere. As Gardiner states, "it is not sufficient to simply add more 'subaltern' public spheres (of a class or ethnic nature, for example) to the mix, as Habermas appears to suggest in response to his critics, because this still maintains the ideal of a generalized public sphere (or spheres) that functions to erase the differences between particular groups" (Gardiner, 2004: 43).

This shows that the inclusion of more and various public spheres to the process does not come to mean the inclusion of all. Democracy, in this context, is not the property of a multitude of views and demands, but is characterized by a unification of diversity around a single, common view and demand, which emerged as the result of the play according to predetermined procedures of moral (and discursive) conduct. Therefore, "Habermas' model does not really allow for the rich encounters of difference that could meet his own demand for a sufficiently concrete and motivating public culture and it does not allow for rich connectivities between 'others' that can develop -with work and with mishaps along the way -without shattering the integrity of our mutual otherness" (Goode, 2005: 87).

The problem of the excluded is common to both Arendt's and Habermas' understanding of politics and democracy with a difference. For Arendt, the excluded is not an important issue since the use of 
faculty of judgment is the sufficient and determining condition to take part in the intersubjective communication as the foundation of politics and this is what she understands by equality: equality among equals. On the other hand, for Habermas, the exclusion is a concern and his approach recognizes plurality, especially based on his formulation of public spheres. However, his procedural understanding of democracy, at the last instance, inevitably conceals differences and asks for their conversion to the collective if these are to take part in the political process. For both thinkers, the political public sphere emerges with the communicative form that intersubjectively bears the faculty of judgment (for Arendt) and discourse ethics (for Habermas). The political nature of the public sphere is related directly to the creation of a collective will around matters of common concern. After this point, Arendt displays no interest in politics: this is the final point for her. However, Habermas continues and is interested in the link between formal and institutionalized structures and the collective will for the sake of societal integration.

This brings us to the question of whether politics is necessarily a moment of agreement and conformity. This question may be answered best by taking the understanding of politics by French philosopher Jacques Rancierè, who assumes that proper politics and democracy are possible via disagreement rather than agreement.

\section{Concluding Remarks: Politics and Democracy as DIS-agreement}

Rancierè's understanding of politics seems to stand opposite to those of Arendt and Habermas. $\mathrm{He}$ begins with defining police and politics on the basis of Aristotle's distinction of speech and voice. Voice is a common characteristic of all living creatures and used by them to express their pain or pleasure. Speech is different from voice in the sense that through voice human beings share what is useful and harmful, what is just and unjust (Rancierè, 1999:1). Police is the level that is represented by speech and it is,

.... an order of bodies that defines the allocation of ways of doing, ways of being, and ways of saying, and sees that those bodies are assigned by the name to a particular place and task; it is an order of the visible and the sayable that sees that a particular activity is visible and another is not, that this speech is understood as discourse and another as noise (Rancierè, 1999: 29).

In this context, "the set of procedures" that enables "the aggregation and consent of collectivities," "the organization of powers," "the distribution of places and roles" and "the systems for legitimizing this distribution" is within the domain of the police and is represented by speech. In the police "men, through the privilege of speech, place their interests in common" (Rancierè, 1999: 27). However, many people are not able to produce speech, but make only "noise" that cannot be heard by the police and so they are excluded at that level. This is the point at which politics comes on to the scene:

Politics exists because those who have no right to be counted as speaking beings make themselves of some account, setting up a community by the fact of placing in common a wrong that is nothing more than this very confrontation, the contradiction of two worlds in a single world: the world where they are and the world where they are not, the world where there is 
something "between" them and those who do not acknowledge them as speaking beings who count and the world where there is nothing (Rancierè, 1999: 27).

Politics, for Rancierè, is the moment of those who have no part, those who do not count, and those who have no qualifications to be included in the police. In other words, politics is something that poses a threat to the police, especially towards changing its common view and order. This disturbance of the police may be "... by introducing either a supplement or a lack" (Rancierè, 2000:124) that cannot be seen, recognized or included by the police.

Rancierè uses the words "blaberon" and "blabber," as frequently seen in Ancient Greek philosophers' works to illustrate his understanding of the nature of politics. Blabber, in this context, means a damage or an unpleasant situation that emerges out of an action of an individual towards the others. According to Rancierè, in fact, blaberon is a voice of wrong; "The blaberon is the voicing of a wrong that falls on the deaf ears of the police" (Panagia, 2006: 90) and "there is a history of the blaberon that coincides with the history of democratic politics" (Panagia, 2006: 90).

Therefore, for Rancierè, the defining characteristic of politics lies in "hearing" the voices of the 'blabber' of those (in the police) who challenge the established order and interests thus 'politicizing' it. Politics, as such, is a matter and product of disagreement and dissensus. It is not a property of, for instance, "communicative action" (Rancierè, 2001:12). (17)

Put in other words, politics (and democracy) is the process whereby blabber is converted into and changes speech. Naturally, those who are in the police will resist and try to prevent that "wrong" from prevailing. This further compels the situation of disagreement and dissensus, thus reproducing the political process. This means, for Rancierè, the subjectification of those who do not find a place in the police. For him, subjectification means "the production through a series of actions of a body and a capacity for enunciation not previously identifiable within a given field of experience, whose identification is thus part of the reconfiguration of the field of experience" (Rancierè, 1999: 35). Overall, democratic politics emerge "whenever there is a miscount and when 'the part of those who have no part' voices a wrong" (Panagia, 2006: 88). Therefore, democracy is not something related with the representation (of those in the police). It is a moment of inclusion of people who are not part of the process. Those who remain outside have the chance to take part as far as they succeed in sustaining their subjectification and convert the police.

In summary, the participants of the political public sphere(s) of Arendt and Habermas are those who have qualifications, who are counted and have a part in the police. Both thinkers exclude those who make noises, but cannot speak, from politics and the public sphere. As the result, Habermas's and Arendt's conception of the public sphere is not a political one, but a means of the maintenance of the existing order.

\section{NOTES}

1. It should be stated that some authors do not agree with this argument. For example, see Villa (1997), Canovan (1983) and Isaac (1992). 
2. Benhabib prefers to call the type of action that takes place in associative public sphere "narrative model of action" and defines it as an "... action embedded in a "web of relationships and enacted stories" (2000: 125).

3. For example, Benhabib argues that "The agonistic political space of the polis was only possible because large groups of human beings like women, slaves, laborers, non-citizen residents, and all non-Greeks were excluded from it and made possible through their 'labor' for the daily necessities of life that 'leisure for politics' which the few enjoyed"' (1992: 91).

4. She notes: "The proportion (of the citizens to the excluded) varied and is certainly exaggerated in Xenophon's report from Sparta, where among four thousand people in the market place, a foreigner counted no more than sixty citizens" (Arendt, 1958: 31, endnote 23, my emphasis).

5. One of the reasons that Arendt settles the understanding of faculty of judgment into the public sphere and thus to politics is establishing a link between the emergence of totalitarianism and the absence of judgment. According to D'Entrèves, "Faced with the horror and the unprecedentedness of the Holocaust, Arendt had to reconceive our categories and standards of moral and political judgment. Her participation at the trial of Eichmann in the 1960s made her acutely aware of the need to come with and to judge a reality that defied human comprehension" (1994: 12). It seems that she thought that the problem with Eichmann was his lack of thought and absence of judgment.

6. This is the final volume of her book The Life of the Mind. That part was going to be about "judging." This was her last study and it is unfinished.

7. See Deveci (1998).

8. According to Shaklar; (1977: 89) "Politics ought to be an expression of the faculty of judgment. As such it is the appeal of the disinterested spectator to all others who strive to be impartial."

9. This point is a major concern especially for feminism and feminist politics.

10. Habermas does not refer to his early public sphere understanding as he elaborated in The Structural Transformation of the Public Sphere in his recent works. However, as he still attempts to reach democratic politics through the public sphere, and as the influence of that early work is clearly visible, that understanding is worth mentioning. This point is already noted by Calhoun (1992: 31): "Habermas shifted his attention from the institutional construction of a public sphere as the basis for democratic will formation to the validity claims universally implicit in all speech. But the public sphere remains the institutional locus for democratic political practice."

11. In Arendt's thought identity formation as such is realized through the disclosure of everyone to each other within the public sphere.

12. This distinction of Habermas seems to be a kind of the contemporary form of Aristotle's distinction of techne and praxis. In fact, a similar distinction also exists in Arendt's vita activa understanding. 
13. In his later studies, Habermas tries to establish a link between these two levels of society via a procedural understanding of law and the political public sphere. This point will be treated later in this study.

14. Participants should have assumptions "...about the structure of their argumentation in order to reach agreement over disputed claim to truth or rightness. They assume that it prohibits all constraints that would exclude or diminish the equal voice of all concerned and hence that the agreement reached is the unconstrained agreement of a universal communication community. They also assume that all those involved ignore all motives other than the cooperative search for truth in a hypothetical attitude. And finally, they assume that only the force of the better argument may hold sway" (Warnke, 1995: 127).

15. This is similar to Kant's "enlarged mentality." Arendt also places it at the core of her theory.

16. Habermas formulates different forms of discourse that are oriented for different forms of communication in this study: "Moral discourses specialize around the principle of universalization; ethical discourses aim at individual and collective identity; pragmatical discourse relate purposes to means and set priorities among collective goals; legal discourse care for the internal consistency of legal rules; and negotiations develop a culture of fair compromise between nongeneralizable interests" (Teubner, 1998).

17. Zizek summarizes Rancierè's understanding of politics as follows (1999: 234):

Politics as disagreement occurs when those who have no part and who are blabber disturb the established structure of police or the order of the police and "politicize its predicament and disturbs the established police/political structure of the social space, its subdivision in parts, by asserting itself as the stand-in for the Whole and demanding the articulation of its particular position, that is, a new mode of its visibility.

\section{REFERENCES}

Arato, A. (1998). "Procedural Law and Civil Society: Interpreting the Radical Democratic Paradigm," in M. Rosenfeld and A. Arato (eds.), Habermas on Law and Democracy: 26-36. Berkeley: University of California Press.

Arendt, H. (1958). The Human Condition. Chicago and London: The University of Chicago Press.

----- (1968). "The Crisis in Culture," in H. Arendt, Between Past and Future: Eight Exercises in Political Thought: 197-226. New York: Penguin Books.

----- (1968). “Truth and Politics", in H. Arendt, Between Past and Future: Eight Exercises in Political Thought: 227- 264. New York: Penguin Books

----- (1983). Lectures on Kant's Political Philosophy. Chicago: Chicago Press. 
Baynes, K. (1995). "Democracy and the Rechtsstaat: Habermas's Faktizitat und Geltung," in S.K. White (ed.), The Cambridge Companion to Habermas: 201-233. Cambridge: Cambridge University Press.

Bohman, (2004). "Expanding Dialogue: The Internet, the Public Sphere and Prospects for Transnational Democracy," in N. Crossley and J.M. Roberts (eds.), After Habermas: New Perspectives on the Public Sphere: 131-156. Oxford and Malden: Blackwell Publishing/The Sociological Review.

Beiner, R. (1983). “Interpretive Essay,” in H. Arendt, Lectures on Kant's Political Philosophy: 89157. Chicago: Chicago Press.

Benhabib, S. (1992). Situating the Self, Gender, Community and Postmodernism in Contemporary Ethics. Cambridge: Polity Press.

----- (2000). The Reluctant Modernism of Hannah Arendt. Lanham: Rowman and Littlefield Publisher, Inc.

----- (1992). Habermas and the Public Sphere. Cambridge: The MIT Press.

----- (1997). "Plurality, Promises, and Public Spaces," in C. Calhoun et al. (eds.), Hannah Arendt and the Meaning of Politics: 232-259. Minneapolis: University of Minnesota Press.

Calhoun, C. and McGowan, J. (1997). "Introduction: Hannah Arendt and the Meaning of Politics," in C. Calhoun et al. (eds.), Hannah Arendt and the Meaning of Politics: 1-24. Minneapolis: University of Minnesota Press.

Cannovan, M. (1983). "A Case of Distorded Communication: A Note on Habermas and Arendt," Political Theory, 11(1): 105-116.

D'éntréves, M.P. (1994).The Political Philosophy of Hannah Arendt. London and New York: Routledge.

Deflem, M. (1996). "Introduction: Law in Habermas's Theory of Communicative Action," in M. Deflem (ed.), Habermas, Modernity and Law: 1-21. London: Sage.

Deveci, C. (1998). "Siyasetin Sınırı olarak Kamusallık: Arendt'in Kant’tan Çıkarsadıkları,” Doğu Batı, 5: 101-117

Gardiner, M.E. (2004). "Wild Publics and Grotesque Symposiums: Habermas and Bakhtin on Dialogue, Everyday Life and the Public Sphere," in N. Crossley and J.M. Roberts (eds.), After Habermas: New Perspectives on the Public Sphere: 28-49. Oxford and Malden: Blackwell Publishing/The Sociological Review.

Goode L. (2005). Jurgen Habermas: Democracy and the Public Sphere. London: Pluto Press. 
Habermas, J. (1977). “Hannah Arendt's Communications Concept of Power," Social Research, 44(1): $1-22$.

(1984). The Theory of Communicative Action. Vol.1, Reason and the Rationalization of Society. Translated by Thomas McCarty. Boston: Beacon Press.

(1987). The Theory of Communicative Action. Lifeworld and System: A Critique of Functionalist Reason. Vol. 2. Translated by Thomas McCarty. Boston: Beacon Press.

(1989). The Structural Transformation of the Public Sphere: An Inquiry into a Category of Bourgeois Society. Translated by Thomas Burger. Cambridge: MIT Press.

------ (1991). Moral Consciousness and Communicative Action. Translated by Christian Lenhardt and Shierry Weber Nicholsen. Cambridge: MIT Press.

----- (1996). Between Facts and Norms: Contribution to a Discourse Theory of Law and Democracy. Translated by William Rehg. Cambridge: MIT Press.

----- (1998). "Paradigms of Law," in M. Rosenfeld and A. Arato (eds.), Habermas on Law and Democracy: 13-26. Berkeley: University of California Press.

Hirschkop, K. (2004). "Justice and Drama: On Bakhtin as a Complement to Habermas," in N. Crossley and J.M. Roberts (eds.), After Habermas: New Perspectives on the Public Sphere: 49-67. Oxford and Malden: Blackwell Publishing/The Sociological Review.

Isaac, J.C. (1992). Arendt, Camus, and Modern Rebellion. New Haven and London: Yale University Press.

Lenoble, J.(1998). "Law and Undecidability: Toward a New Vision of the Proceduralization of Law," in M. Rosenfeld and A. Arato (eds.), Habermas on Law and Democracy: 37-82. Berkeley: University of California Press.

McAfee, N. (2000). Habermas, Kristeva and Citizenship. London: Cornell University Press.

McCarthy, T. (1989). "Introduction," in J. Habermas, The Structural Transformation of the Public Sphere. Cambridge: MIT Press.

----- (1991). "Introduction,” in J. Habermas, Moral Consciousness and Communicative Action. Translated by Christian Lenhardt and Shierry Weber Nicholsen. Cambridge: MIT Press.

Panagia, D. (2006). The Poetics of Political Thinking. Durham and London: Duke University Press.

Rancierè, J. (1999). Disagreement: Politics and Philosophy. Translated by Julia Rose. MinneapolisLondon: University of Minnesota Press.

------ (2000). “Dissenting Words: A Conversation with Jacques Rancierè,” Diacritics, 30(2): 113-126. 
----- (2001). “Ten Theses on Politics,” Theory and Event, 5(3):1-17.

Riley, P. (1992). "Hannah Arendt on Kant, Truth and Politics," in H. Williams (ed.), Essays on Kant's Political Philosophy: 305-323. Chicago: Chicago University of Press.

Shaklar, J. (1977). "Rethinking the Past" Social Research, 44(1): 80-90.

Teubner, A.J (1998). "De Collisione Discursuum: Communicative Rationalities in Law, Morality, and Politics," in M. Rosenfeld and A. Arato (eds.), Habermas on Law and Democracy: 173-190. Berkeley: University of California Press.

Villa, D.R. (1997). "Hannah Arendt: Modernity, Alienation, and Critique," in C. Calhoun et al. (eds.), Hannah Arendt and the Meaning of Politics: 179-207. Minneapolis and London: University of Minnesota Press.

Warren, M.E. (1995). "The Self in Discoursive Democracy," in S.K. White (ed.), The Cambridge Companion to Habermas: 167-201. Cambridge, New York: Cambridge University Press.

Warnke, G. (1995). "Communicative Rationality and Cultural Values," in S.K. White (ed.), The Cambridge Companion to Habermas: 120-142. Cambridge, New York: Cambridge University Press.

Weintraub, J. (1997). "The Theory and Politics of the Public/Private Distinction," in J. Weintraub et al., (eds.), Public and Private in Thought and Practice: 1-43. Chicago and London: The University and Chicago Press.

White, S.K. (1995). "Reason, Modernity, and Democracy," in S.K. White (ed.), The Cambridge Companion to Habermas: 3-19. Cambridge: Cambridge University Press.

Zizek, S. (1999). The Ticklish Subject: The Absent Centre of Political Ontology. London and New York: Verso 